\title{
CHRONOLOGY OF THE ATMOSPHERIC MERCURY IN LAGOA DA PATA BASIN, UPPER RIO NEGRO REGION OF BRAZILIAN AMAZON
}

\author{
G M Santos ${ }^{1,2} \bullet$ R C Cordeiro ${ }^{3} \bullet$ E V Silva Filho $^{3} \bullet$ B Turcq $^{5} \bullet$ L D Lacerda $^{3} \bullet$ L K Fifield $^{1}$ \\ P R S Gomes ${ }^{4} \bullet$ P A Hausladen ${ }^{1}$ A A Sifeddine ${ }^{3,5} \bullet$ A L S Albuquerque $^{3}$
}

\begin{abstract}
We present prehistoric mercury accumulation rates in a dated sediment core from Lagoa da Pata, a remote lake in São Gabriel da Cachoeira, northern Amazon. The sediment samples were subdivided for mercury and radiocarbon analyses. A group of 18 samples have been prepared at ANU for ${ }^{14} \mathrm{C}$ dating by accelerator mass spectrometry (AMS). The dating results show a good correlation with depth in the core, down to 41,500 BP. Three distinct sections are clearly identified in the core. They consist of upper and lower organic-rich layers, separated by an inorganic layer which represents a short period of rapid accumulation around $18 \mathrm{ka} \mathrm{BP}$. The mercury accumulation rate is found to be larger in the upper layer (18 ka to present) than in the lower one ( $41 \mathrm{ka}$ to $25 \mathrm{ka}$ ), by a factor of three. The larger accumulation rate of mercury is probably associated with warmer temperatures and a higher frequency of forest fires during the Holocene.
\end{abstract}

\section{INTRODUCTION}

This work is part of a project studying paleoclimatic and paleoenvironmental changes in the Brazilian Amazon over the past 40,000 years, using geochemical tracers of natural and anthropogenic processes. Among these, mercury has proved to be a reliable tracer of paleoclimatic conditions, due to its global scale atmospheric transport and long residence time in the atmosphere (Nriagu 1996; Engstrom and Swain 1997). It has been shown that changes in atmospheric mercury deposition reflects changes in the ocean temperature and primary production (Vandal et al. 1993) of average regional temperature (Marínez-Cortizas et al. 1999), and of increases in the frequency of natural fires due to periods of drier climate (Lacerda et al. 1999). In addition, it reflects past mining activities (Lacerda and Salomons 1998), and the evolution of industrialization (Pirrone et al. 1998). Thus, at least in regions where the geological background of mercury is negligible, such as in the Amazon region, the mercury archived in sediment cores of a remote lake may be a powerful tool for the interpretation of paleoclimatology and paleoecology of the region.

Remote Amazon lakes usually have a very low sedimentation rate, and anthropogenic activities are recorded only in the uppermost millimeters of sediment. Anthropogenic sources of mercury in Brazil are mainly gold mining, and industrial activities (Lacerda 1995, 1997; Lacerda and Salomons 1998) during the second half of the 20th century, but this is not the subject of the present work.

The available data for mercury deposition rates in the Amazon region are still too fragmentary to allow any firm conclusions due to a paucity of reliable dating and the large geographical spread of the results. Preliminary studies have suggested that average background mercury deposition rates over the Amazon were fairly constant at 1.7 to $2.6 \mu \mathrm{g} \mathrm{m}^{-2} \mathrm{yr}^{-1}$ (Lacerda et al. 1999). During the last glacial maximum (LGM), however, mercury deposition rates more than doubled, reaching about $5.3 \mu \mathrm{g} \mathrm{m}^{-2} \mathrm{yr}^{-1}$. Also, during more recent periods of drier climates characterized by a high frequency of forest fires, mercury deposition rates were higher.

${ }^{1}$ Department of Nuclear Physics, Research School of Physical Sciences and Engineering, Australian National University, A.C.T. 0200, Australia

${ }^{2}$ Corresponding author: Guaciara Macêdo dos Santos, Department of Nuclear Physics, Research School of Physical Sciences and Engineering, Australian National University, A.C.T. 0200, Australia. E-mail: gss103@nuc.anu.edu.au. Supported by a fellowship from CNPq, Brazil.

${ }^{3}$ Departamento de Geoquímica, Universidade Federal Fluminense, Niterói, R.J., 24020-007, Brazil

${ }^{4}$ Instituto de Física, Universidade Federal Fluminense, Niterói, R.J., 24210-340, Brazil

${ }^{5}$ Institute de Recherche pour L'Development, Bondy, France

(C) 2001 by the Arizona Board of Regents on behalf of the University of Arizona

Radiocarbon, Vol 43, Nr 2B 2001, p 801-808

Proceedings of the 17 th International ${ }^{14} \mathrm{C}$ Conference, edited by I Carmi and E Boaretto 
In the present study, results from a detailed core from north Amazonia are presented. The higher frequency of dating (up to 18 layers from a $1.0 \mathrm{~m}$ core) has allowed a much more detailed characterization of the sedimentation rates and mercury deposition rates compared to previously published data.

\section{The Studied Site}

Lake sediment samples were collected from the Lagoa da Pata at the Morro dos Seis Lagos (Six Lakes Hill). Lagoa da Pata is a small $\left(100,000 \mathrm{~m}^{2}\right)$ headwater lake, which occupies a substantial fraction (55\%) of its catchment. It is controlled by the flooding dynamics of the great river of the Amazon River, and is therefore expected to be a good atmospheric deposition catcher (Porcella 1996). Lagoa da Pata is important because it is first remote lake studied in Amazon region to span glacial times, which allows the interpretation of $\mathrm{Hg}$ deposition rates to pre-historic background. It is located at latitude $0^{\circ} 16^{\prime} \mathrm{N}$ and longitude $66^{\circ} 41^{\prime} \mathrm{W}$, inside the Pico da Neblina National Park, São Gabriel da Cachoeira, northern Amazon State, approximately $600 \mathrm{~km}$ northwest from Manaus, not far from the Venezuela border. The lake, which is about $400 \mathrm{~m}$ long and $4 \mathrm{~m}$ deep, is surrounded by a dense tropical rain forest and is remote from human activities. The climate is warm and humid, with a total annual precipitation of the order of $2900 \mathrm{~mm}$, without a dry season. Other details on lake sediment stratigraphy and palynology have been previously published (Colinvaux et al. 1996a). Lake water is very soft ( 2 to $5 \mu \mathrm{S}$ ), $\mathrm{pH} \sim 5$, with a temperature range of $28-30^{\circ} \mathrm{C}$ (Gomes et al. 1990; Justo and Souza 1984). The lack of any mercury-bearing geological formations in the lake's basin suggests that atmospheric deposition is the most significant source of mercury to Lagoa da Pata sediments.

The main pigments (chlorophyll a, b, c, carotenoids and phaeopigments) were analyzed, by colorimetry, in the column of water. Concentrations of all these pigments were low: chlorophyll a, $1.56 \mathrm{mg}$ $\mathrm{m}^{-3}$; chlorophyll b, $1.09 \mathrm{mg} \mathrm{m}^{-3}$; chlorophyll c, $3.01 \mathrm{mg} \mathrm{m}^{-3}$; carotenoids, $2.08 \mathrm{mg} \mathrm{m}^{-3}$. Phaeopigments (degraded chlorophyll) were also very low. The main chemical and physical-chemical parameters of the Lagoa da Pata water were very similar to those determined in nearby rainwater (Table 1), indicating that there is little addition of nutrients through run off from the catchments. The primary productivity of the lake is probably maintained by the internal cycling of nutrients promoted by the high temperature $\left(28^{\circ} \mathrm{C}\right)$ of the system.

Table 1 Some physical-chemical parameters of the Lagoa da Pata and rain water

\begin{tabular}{lcccccc}
\hline & $\mathrm{PH}$ & $\begin{array}{c}\text { Conductivity } \\
(\mu \mathrm{s} / \mathrm{cm})\end{array}$ & $\begin{array}{c}\mathrm{Cl}^{-1} \\
(\mu \mathrm{Mol} / \mathrm{L})\end{array}$ & $\begin{array}{c}\mathrm{NO}_{2} \\
(\mu \mathrm{Mol} / \mathrm{L})\end{array}$ & $\begin{array}{c}\mathrm{NO}_{3} \\
(\mu \mathrm{Mol} / \mathrm{L})\end{array}$ & $\begin{array}{c}\mathrm{SO}_{4} \\
(\mu \mathrm{Mol} / \mathrm{L})\end{array}$ \\
\hline Lagoa da Pata surface & 5.05 & 6.81 & 5.20 & 2.91 & 0.54 & 1.32 \\
Lagoa da Pata 5 m & 4.99 & 6.72 & 2.54 & 3.05 & 0.37 & 0.99 \\
$\begin{array}{l}\text { Rainwater } \\
\text { 16/05/1997 to }\end{array}$ & 5.23 & 4.78 & 8.80 & 1.91 & 0.59 & 0.90 \\
$\begin{array}{l}\text { 19/05/1997 } \\
\text { Rainwater }\end{array}$ & & & & & & \\
$\begin{array}{l}\text { 19/05/1997 to } \\
\text { 22/05/1997 }\end{array}$ & 5.35 & 3.48 & 2.47 & 1.45 & & 1.27 \\
$\begin{array}{l}\text { Rainwater } \\
\text { 22/05/1997 to }\end{array}$ & 5.57 & 3.49 & 5.34 & 2.02 & 0.38 & 0.97 \\
24/05/1997 & & & & & & \\
\hline
\end{tabular}

We have assumed that the organic carbon in the sediment was in isotopic equilibrium with the contemporaneous atmosphere at the time of deposition. This assumption is supported by the observation 
that the water in Lagoa da Pata has low $\mathrm{pH}$, very low conductivity and therefore low $\mathrm{CaCO}_{3}$, and that the drainage basin has an iron rich crust.

\section{MATERIAL AND METHODS}

Samples also were collected in accordance with accepted protocols (Porcella 1996). A lake sediment core (called LPT IV) approximately $1.0 \mathrm{~m}$ in length was collected with a piston corer in a sub-basin of the lake at a water depth of $5 \mathrm{~m}$. The core was sliced in 2-cm layers. Samples were stored in acidcleaned plastic bags and frozen for transport.

In the laboratory, the sediment samples were dried prior to digestion. Duplicate sub-samples of about $1.0 \mathrm{~g}$ were digested with $50 \%$ aqua regia for one hour at $70{ }^{\circ} \mathrm{C}$ in a closed system. Mercury was analyzed through CVAAS (cold vapor atomic absorption spectrometry), in a Bacharach MAS50D mercury analyzer system. Differences between duplicates were always smaller than $10 \%$. Simultaneous determination of mercury in reference standards (NIST-USA, "Buffalo River sediments"; with $60 \mathrm{ng} \mathrm{g}^{-1}$ of mercury) was performed, using the same analytical procedure, and the results were $58 \pm 6 \mathrm{ng} \mathrm{g}^{-1}(\mathrm{n}=15)$. The detection limit of the method, taken to be three times the value of reagent blanks, was $0.4 \mathrm{ng} \mathrm{g}^{-1}$.

The bulk density (grams dry sediment $/ \mathrm{cm}^{3}$ bulk sediment) of each layer was obtained by taking out $8 \mathrm{~cm}^{3}$ of a wet sediment section and drying it at $60^{\circ} \mathrm{C}$ until a constant weight was reached. Total organic carbon (TOC) and nitrogen were measured in a CHN automatic analyzer at Environmental Isotope Laboratory, University of Waterloo, Canada. Mercury fluxes were obtained from the product of the sedimentation rate $\left(\mathrm{cm} \mathrm{yr}^{-1}\right)$, bulk density $\left(\mathrm{g} \mathrm{cm}^{-3}\right)$, and mercury concentration $\left(\mathrm{ng} \mathrm{g}^{-1}\right)$.

\section{Radiocarbon Dating}

A group of 18 samples was selected for the determination of the chronology of the core. Samples of approximately $1 \mathrm{~g}$ of lake sediment were sent to the Australian National University (ANU) to be prepared and dated by AMS. All samples were acid washed with $10 \% \mathrm{HCl}$ prior to a conventional acid-base-acid (ABA) pretreatment procedure. This was followed by combustion to $\mathrm{CO}_{2}$ at $900{ }^{\circ} \mathrm{C}$ in a closed tube containing $\mathrm{CuO}$ and silver wire, and conversion to graphite by catalytic reduction of the $\mathrm{CO}_{2}$ on iron powder in the presence of hydrogen (Santos 1999a; Santos et al. 1999b).

The fraction of material remaining after the chemical pretreatment procedure ranged from $20 \%$ to $70 \%$ of the original amount. Samples at the lower end of this range came from between 20 and $60 \mathrm{~cm}$ of the core where the total organic carbon content of the bulk sediments were lowest, as shown in Figure 1. In order to determine the radiocarbon backgrounds for the combustion and graphitization procedures, a sample of Sri Lankan graphite ("infinitely" old) was processed in the same way as the natural samples.

Conventional ${ }^{14} \mathrm{C}$ ages (in BP; Stuiver and Polach 1977) were determined by accelerator mass spectrometry (AMS) using the 14UD accelerator at the ANU. Results are shown in Table 2. The uncertainties shown are the statistical errors only. The reproducibility of the ANU system, as determined from multiple measurements on standards, is approximately $1.5 \%$. Figure 2 shows the ${ }^{14} \mathrm{C}$ chronology of the LPT IV core as a function of cumulative mass $\mathrm{g} / \mathrm{cm}^{2}$. Conventional ${ }^{14} \mathrm{C}$ ages rather than calendar years BP have been employed in order to compare our results with the limited data covering the Holocene and prehistoric period (Lacerda et al. 1999; Colinvaux et al. 1996a; Turcq et al. 1998) in the Amazon region, which have been reported as conventional ${ }^{14} \mathrm{C}$ ages. This choice is also more appropriate for ${ }^{14} \mathrm{C}$ ages beyond 20,000 BP, where the calibration in terms of calendar years becomes more uncertain. As ${ }^{14} \mathrm{C}$ ages appear younger than true calendar ages (by about 1000 years 
at $10,000{ }^{14} \mathrm{C}$ years ago, and by about 4000 years at $20,000{ }^{14} \mathrm{C}$ years ago), true calendar ages will be somewhat older than the values reported here, but this does not affect the conclusions of this work.

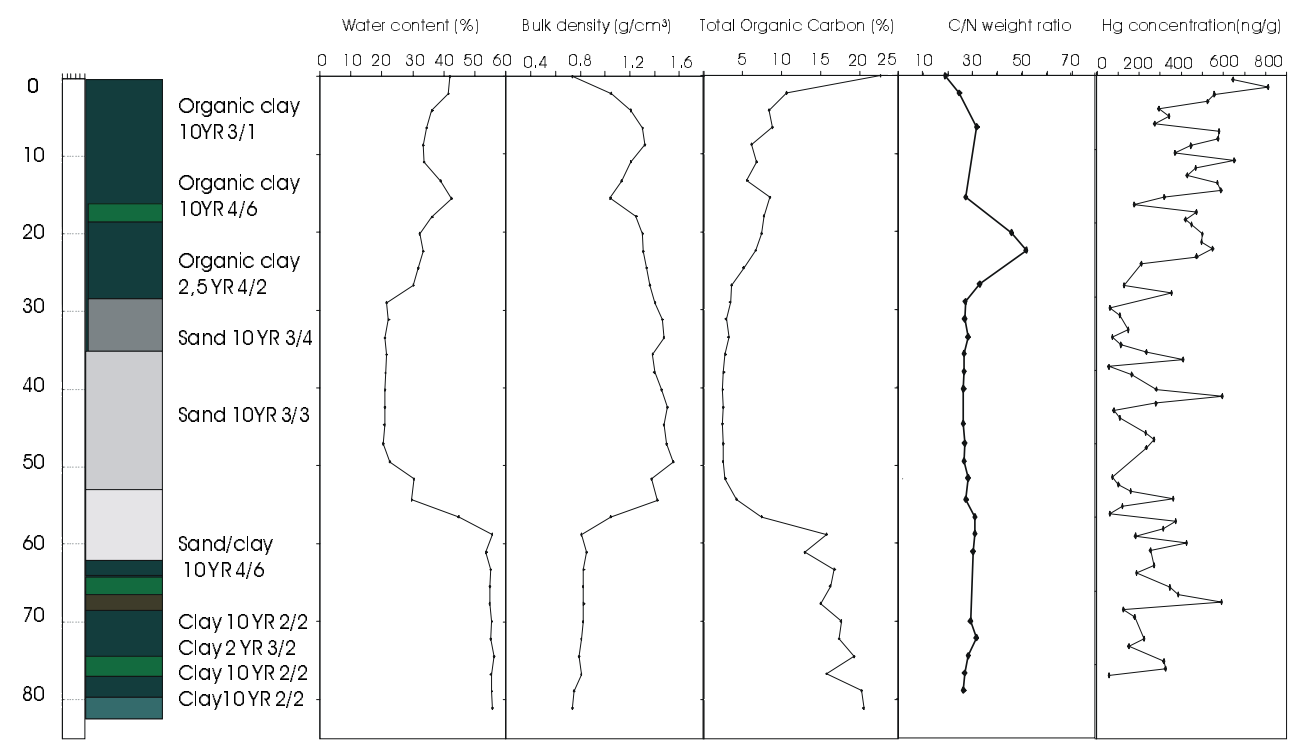

Figure 1 Water content, bulk density, total carbon concentration, carbon/nitrogen ratio and mercury concentration as a function of depth in the core

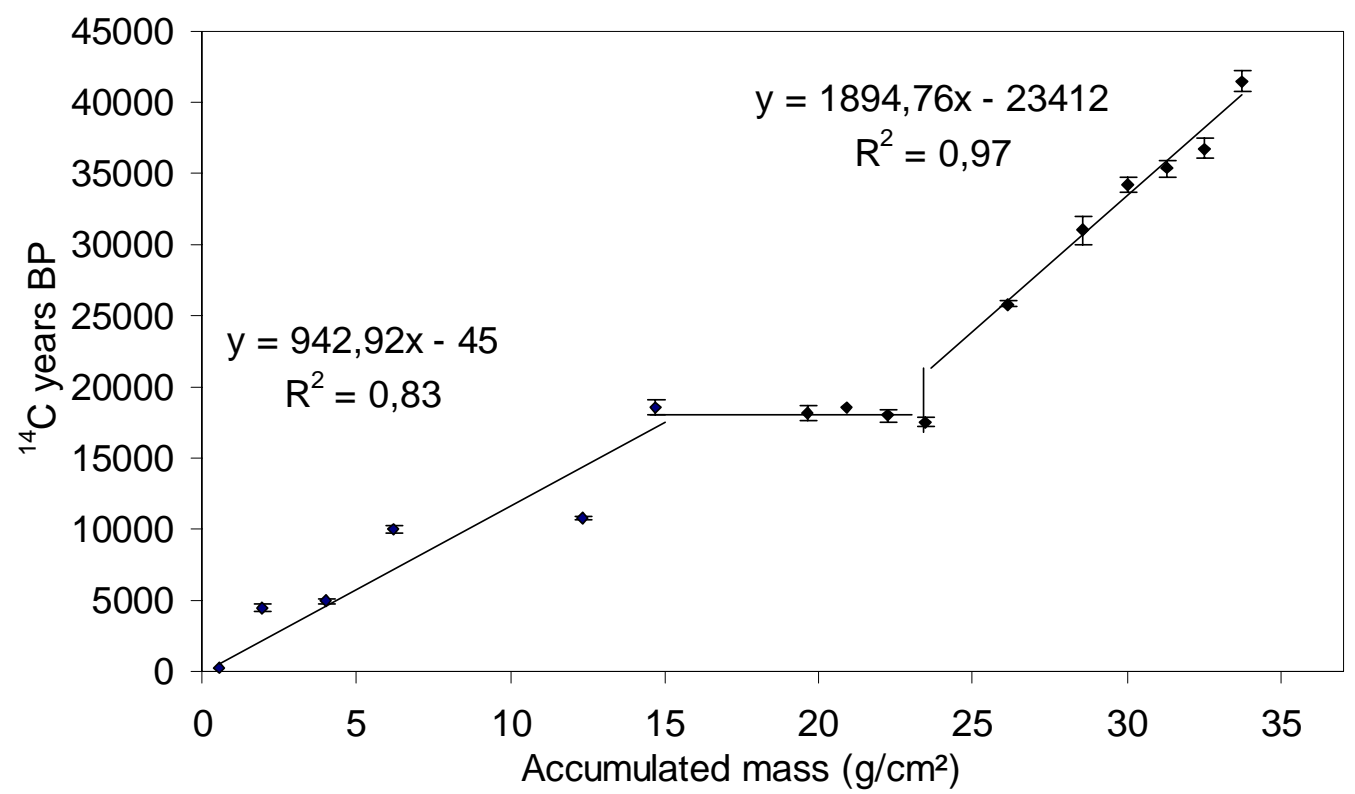

Figure 2 Radiocarbon chronology as a function of the cumulative mass 
Table 2 AMS ${ }^{14} \mathrm{C}$ dating of a lake-sediment core from Lagoa da Pata, São Gabriel da Cachoeira

\begin{tabular}{|c|c|c|c|c|c|c|c|}
\hline $\mathrm{Nr}$ & Sample name & $\begin{array}{l}\text { Depth } \\
(\mathrm{cm})\end{array}$ & $\begin{array}{l}\text { ANUA }^{a} \\
\text { number }\end{array}$ & $\% \mathrm{M}$ & $\begin{array}{c}\% \mathrm{M} \text { error } \\
(1 \sigma)\end{array}$ & $\begin{array}{c}{ }^{14} \mathrm{C} \text { age } \\
(\mathrm{BP})^{\mathrm{b}}\end{array}$ & $\begin{array}{l}\text { Age error } \\
\qquad(1 \sigma)\end{array}$ \\
\hline 0 & Sri Lankan graphite & & 13002 & 0.3 & 0.1 & 47,220 & 2300 \\
\hline 1 & LPT4-33 & $4.4-6.6$ & 12319 & 57.2 & 1.5 & 4330 & 210 \\
\hline 2 & LPT4-35 & $8.8-11.0$ & 12318 & 54.0 & 1.3 & 4800 & 200 \\
\hline 3 & LPT4-37 & $13.4-15.6$ & 12317 & 28.6 & 1.0 & 9900 & 270 \\
\hline $4^{c}$ & LPT4-39 & $18.0-20.0$ & 12316 & 56.5 & 1.3 & 4430 & 180 \\
\hline 5 & LPT4-43 & $26.8-28.8$ & 13426 & 26.1 & 0.6 & 10,650 & 180 \\
\hline 6 & LPT4-45 & $31.2-33.4$ & 12315 & 9.9 & 0.6 & 18,420 & 510 \\
\hline $7^{\mathrm{c}}$ & LPT4-47 & $35.7-38.1$ & 13113 & 6.8 & 0.7 & 21,400 & 810 \\
\hline 8 & LPT4-49 & $40.2-42.4$ & 12314 & 10.4 & 0.6 & 18,020 & 485 \\
\hline 9 & LPT4-50 & $42.5-44.7$ & 13112 & 9.9 & 0.3 & 18,410 & 275 \\
\hline 10 & LPT4-51 & $44.7-46.9$ & 13110 & 10.6 & 0.3 & 17,850 & 210 \\
\hline 11 & LPT4-52 & $47.2-49.4$ & 13425 & 11.2 & 0.2 & 17,410 & 155 \\
\hline 12 & LPT4-54 & $51.7-53.9$ & 13512 & 4.0 & 0.5 & 25,690 & 950 \\
\hline 13 & LPT4-56 & $56.6-58.8$ & 13107 & 2.1 & 0.1 & 30,845 & 510 \\
\hline 14 & LPT4-58 & $61.1-63.3$ & 13106 & 1.4 & 0.1 & 34,080 & 640 \\
\hline 15 & LPT4-60 & $65.0-67.7$ & 13105 & 1.2 & 0.1 & 35,180 & 680 \\
\hline 16 & LPT4-62 & $70.4-72.2$ & 13104 & 1.0 & 0.1 & 36,610 & 780 \\
\hline 17 & LPT4-64 & $74.5-76.7$ & 13103 & 0.6 & 0.1 & 41,360 & 1060 \\
\hline $18^{c}$ & LPT4-67 & $81.1-83.3$ & 13102 & 1.3 & 0.1 & 34,740 & 690 \\
\hline
\end{tabular}

${ }^{\mathrm{a}}$ Code number for ANU-AMS measurements

${ }^{\mathrm{b}} \mathrm{A}$ blank correction of $0.3 \pm 0.1 \mathrm{pMC}$ has been subtracted from the measured pMC for each sample. Measurements of $\delta^{13} \mathrm{C}$ for a subset of these samples clustered tightly around $-34 \%$, and this value was assumed for all samples in calculating the ${ }^{14} \mathrm{C}$ age.

${ }^{\mathrm{c}}$ Samples 4, 7, and 18 are out of sequence. We suspect that sample 18 was contaminated during the core collection procedure. Further analysis will be require to understand these anomalous results.

\section{RESULTS AND DISCUSSIONS}

The ages obtained show a good correlation with depth in the core with ${ }^{14} \mathrm{C}$ ages ranging between 4500 and 41,500 BP. Three samples, however, do not follow the general trend. The deepest sample, 18 , appears to be younger than sample 17, probably due to contamination from young surface material during the core collection procedure. In addition, samples 4 and 7 are out of sequence. Although there is no evidence in the lithology of this section for a sharp erosion event, which could explain an inversion in the sediment layers, these samples were not used in defining the sedimentation rates (Figure 2). Further analysis will be required to understand these anomalous results.

From this chronology, sedimentation rates could be derived. They were calculated using a linear model correlating ages and depths. Three different sedimentation regimes are evident, which are also reflected in other physical and chemical properties of the deposited material as can be seen in Figure 1. Four time intervals representing different paleoclimatic processes that influenced the characteristics of the deposited material can be identified.

1. From 42 to $26 \mathrm{ka} \mathrm{BP}$, corresponding to depths in the core of $76-52 \mathrm{~cm}$, the sedimentation rate is steady at $0.00165 \mathrm{~cm} / \mathrm{yr}$. This facie consists of organic-rich clay with average water content of about $45.6 \%$ and an average bulk density of $0.76 \mathrm{~g} \mathrm{~cm}^{-3}$. The average total organic carbon concentration was highest in this section $(12.3 \%)$ with a $\mathrm{C} / \mathrm{N}$ weight ratio of about 28.5 , suggesting an allochtounous lignocellulosic material as the major carbon source.

2. At about $50 \mathrm{~cm}$ in the core, there is a hiatus corresponding to ages between 25,700 and $18,000 \mathrm{BP}$. The same feature is evident in another core from the same lake (Colinvaux et al. 
1996a) as well as in six more sedimentation core records in lowland tropical forests in Brazil (Ledru et al. 1998), but at present, a satisfactory explanation is lacking.

3. At around 18,000 BP, there appears to have been a sudden input of $\sim 20 \mathrm{~cm}$ of clastic material. This is represented by a sandy facies, which exhibits lower carbon and water contents $(2.7 \%$ and $21.2 \%$, respectively) and higher bulk density $\left(1.25 \mathrm{~g} \mathrm{~cm}^{-3}\right)$ than the layers above and below it. It also shows the lowest $\mathrm{C} / \mathrm{N}$ ratio (26.8). This event may have been due to the occurrence of sudden and torrential rains, typical of dry climate, on a very local scale at about $18 \mathrm{ka} \mathrm{BP}$. The sedimentation rate, therefore, was very rapid over the depth range from 54 to $31 \mathrm{~cm}$ and cannot be calculated from the data.

4. During the tardiglacial and the Holocene periods the sedimentation rate has been reasonably constant at $0.00192 \mathrm{~cm} / \mathrm{yr}$. This facie of the core is again organic-rich clay with average water content of $37.0 \%$ and average bulk density of $1.01 \mathrm{~g} \mathrm{~cm}^{-3}$. Total organic carbon concentrations present the highest value in the top of the core reaching $22.9 \%$. The $\mathrm{C} / \mathrm{N}$ weight ratio (29.7) in this phase is similar to the precedent phases.

Figure 3 shows mercury deposition rates for the two periods where deposition rates are well defined. Table 3 summarizes, for these two periods, the average values of mercury concentration and deposition rate, as well as the average of the other parameters shown in Figure 1. Although there are significant fluctuations in the mercury flux, it is clear from Figure 3 and Table 3 that the average flux since the LGM was almost a factor of three higher than prior to the LGM. Natural emissions of $\mathrm{Hg}$ in Brazil are very small due to a lack of volcanic activity and significant $\mathrm{Hg}$-ore deposits, and arise from re-volatilization of deposited $\mathrm{Hg}$ from soils and water, and from long-range atmospheric transport. The observed increase in mercury deposition rate after the LGM, may therefore be linked to drier periods and a higher frequency of forest fires, which release larger amounts of mercury from the biomass and the soils. Evidence for an increased frequency of forest fires comes from charcoal deposits in soils (Pessenda et al. 1998a, 1998b) and sediments (Cordeiro 1995; Cordeiro et al. 1997; Lacerda et al. 1999; Turcq et al. 1998).

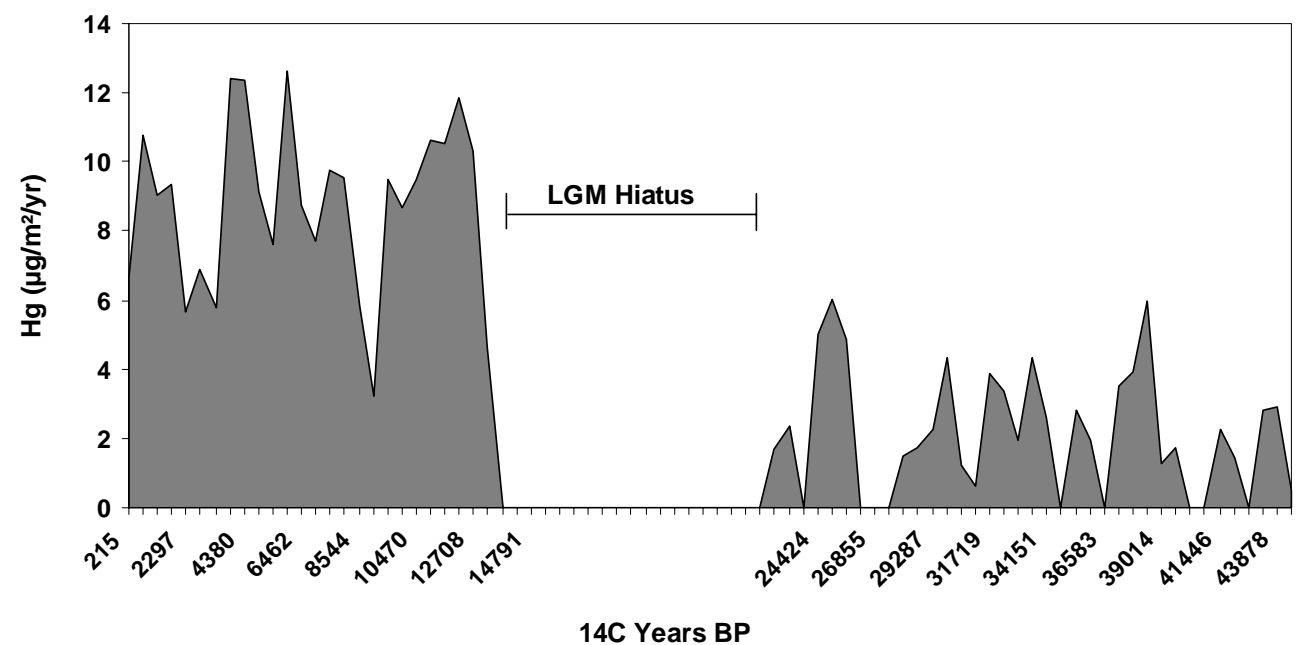

Figure 3 Mercury accumulation rates, in the sediment from Lagoa da Pata at São Gabriel da Cachoeira, as a function of time before and after the Last Glacial Maximum 
In the clastic event about 18,000 years ago, mercury concentrations were highly variable, but the average value of $210 \pm 160 \mathrm{ng} \mathrm{g}^{-1}$ is similar to the pre-LGM value of $233 \pm 130 \mathrm{ng} \mathrm{g}^{-1}$ (Table 2). In contrast, the post-LGM value of $453 \pm 155 \mathrm{ng} \mathrm{g}^{-1}$ is considerably higher than either. The pre-LGM mercury concentrations observed here are, however, significantly lower than those observed elsewhere in the world (Lacerda et al. 1999).

Table 3 Average values of water content, bulk density, total organic carbon concentration, carbon/ nitrogen ratio, and mercury concentration and flux for three facies corresponding to the periods indicated.

\begin{tabular}{lcccccc}
\hline & & $\begin{array}{c}\text { Bulk } \\
\text { density } \\
\end{array}$ & $\begin{array}{c}\text { Total organic } \\
\text { carbon }(\%)\end{array}$ & $\mathrm{C} / \mathrm{N}$ & $\begin{array}{c}\mathrm{Hg} \\
\text { concentration } \\
\left(\mathrm{ng} \mathrm{cm}^{-1}\right)\end{array}$ & $\begin{array}{c}\mathrm{Hg} \text { flux } \\
\left(\mu \mathrm{g} \mathrm{m}^{-2} \mathrm{yr}^{-1}\right)\end{array}$ \\
\hline $\begin{array}{l}\text { Before LGM } \\
\text { 41,500 to } \sim 26,000\end{array}$ & 45.6 & 0.76 & 12.3 & 28,5 & $233 \pm 130$ & $2.8 \pm 1.5$ \\
$\sim 18,000$ & 21.2 & 1.25 & 2.7 & 26,8 & $210 \pm 161$ & \\
18,000 to present & 37.0 & 1.01 & 9.3 & 29,7 & $453 \pm 155$ & $8.6 \pm 2.6$ \\
\hline
\end{tabular}

\section{CONCLUSIONS}

The distribution of mercury in lake sediment cores can be used as a tracer of paleoclimatic conditions and may be a powerful tool for the interpretation of paleoclimatology and paleoecology of the region. In the present study, mercury accumulation rates were derived from a sediment core from Lagoa da Pata, a remote lake in Northern Amazon. A good chronology for this core, which spanned the age range from 4.3 to $41.4 \mathrm{ka} \mathrm{BP}$ was obtained by $\mathrm{AMS}{ }^{14} \mathrm{C}$ dating of the sediments following an ABA pretreatment regime.

The principal finding of this work was that average mercury deposition rates were three times higher after the LGM than before it. This is probably associated with warmer temperatures and a higher frequency of forest fires during the Holocene.

The present results are in broad agreement with the limited data from previous work in the Amazon region (Colinvaux et al. 1996a,b; Ledru et al. 1998; Turcq et al. 1998). The more detailed chronology obtained in the present work, however, allows a more reliable characterization of the sedimentation rates, and hence of mercury deposition rates, than previously published for the Amazon region.

\section{ACKNOWLEDGMENTS}

The authors thank Christian Turney and Michael Bird (Research School of Earth Sciences, ANU) for useful advice and discussion on pretreatment strategies for lake sediment. G M Santos acknowledges the provision of fellowship from the Conselho Nacional de Desenvolvimento Científico e Tecnológico (CNPq). The other Brazilian authors would like to thank the CNPq for their partial financial support. They also thank IBAMA and Força Aérea Brasileira (CAN) for logistical support and transport during the field work at Six Lakes Hill, Patricia Moreira Turcq and Josias Azeredo Barbosa for the determination of the pigments and Dr William Zamboni de Mello for the ion determinations in the water column. 


\section{REFERENCES}

Colinvaux PA, de Oliveira PE, Moreno JE, Miller MC, Bush MB. 1996a. A long pollen record from lowland Amazonia: forest and cooling in glacial times. Science 274:85-8.

Colinvaux PA, Liu KB, de Oliveira PE, Bush MB, Miller MC, Kannan MS. 1996b. Temperature depression in the lowland tropics in glacial times. Climatic Change 32:19-33.

Cordeiro RC. 1995. Mudanças paleoambientais e ocorrência de incêndios nos últimos 7400 anos, na região de Carajás, Pará. Master Degree Thesis. Universidade Federal Fluminense. Niteroi, Brazil. 144 p.

Cordeiro RC, Turcq B, Oliveira da Silva A, Suguio K. 1997. Holocene environmental changes in Carajás region (Pará, Brazil) recorded by lacustrine deposits. Verh. Internat. Verein. Limnol. 26: 814-7.

Engstrom DR, Swain EB. 1997. Recent declines in atmospheric mercury deposition in the upper Midwest. Environmental Science \& Technology 31:960-7.

Gomes CB, Ruberti E, Morbidelli L. 1990. Journal of South American Earth Sciences 3(51).

Justo LC, Souza MM. 1984. Jazida de Nióbio do Morro dos Seis Lagos, Amazonas. Capítulo XXXVII. Principais Depósitos Minerais do Brasil. Volume 2. Rio de Janeiro: Departamento Nacional da Produção Mineral.

Lacerda LD. 1995. Amazon mercury emissions. Nature 374:20-1.

Lacerda LD. 1997. Evolution of mercury contamination in Brazil. Water, Air and Soil Pollution 97: 247-55.

Lacerda LD, Salomons W. 1998. Mercury from gold and silver mining: a chemical time-bomb? Berlin: Springer Verlag. $146 \mathrm{p}$.

Lacerda LD, Ribeiro MG, Cordeiro RC, Sifeddine A, Turcq B. 1999. Atmospheric mercury deposition over Brazil during the past 30,000 years. Ciência e Cultura, Journal of the Brazilian Society for the Advancement of Sciences 51(5/6):363-71

Ledru MP, Bertaux J, Sifeddine A, Suguio K. 1998. Absence of Last Glacial Maximum records in lowland tropical forests. Quaternary Research 49:233-7

Marínez-Cortizas A, Pontevedra-Pombal X, GarciaRodeja E, Nóvoa-Muñoz JC, Shotyk W. 1999. Mer- cury in Spanish peat bog: archive of climate change and atmospheric metal deposition. Science 284:93942.

Nriagu JO. 1996. A history of global metal pollution. Science 272:223-4.

Pessenda LCR, Gomes BM, Aravena R, Ribeiro AS, Boulet R, Gouveia SEM. 1998a. The carbon isotope record in soils along a forest-cerrado ecosystem transect: implications for vegetation changes in the Rondônia State, southwestern Brazilian Amazon region. The Holocene 8(5):599-603.

Pessenda LCR, Valencia EPE, Aravena R, Telles ECC, Boulet R. 1998b. Paleoclimate studies in Brazil using carbon isotope studies in soils. In: Wasserman JC, Silva Filho EV, Villas-Boas R, editors. Environmental Geochemistry in the Tropics. Springer Verlag.

Pirrone N, Allegrini I, Keeler GJ, Nriagu JO, Rossman R, Robbins JA. 1998. Historical atmospheric emissions and depositions in North america compared to mercury accumulations in sedimentary records. Atmospheric Environment 32(5):929-40.

Porcella D. 1996. Protocol for estimating historic atmospheric mercury deposition: Technical Report - TR 106768. Electric Power Research Institute, Palo Alto, California

Santos GM. 1999a. Implementação e Aplicação de AMS (Espectrometria de Massa com uso de Aceleradores) [PhD thesis]. Universidade Federal Fluminense. Niteroi, Brazil. $183 \mathrm{p}$.

Santos GM, Gomes PRS, Yokoyama Y, di Tada ML, Cresswell R, Fifield KL. 1999b. Datação por ${ }^{14} \mathrm{C}$ através de Espectrometria de Massa com Aceleradores. Revista de Física Aplicada e Instrumentação 14(1): 1-12.

Stuiver M, Polach HA. 1977. Discussion: reporting of ${ }^{14} \mathrm{C}$ data. Radiocarbon 19(2):355-63.

Turcq B, Siffedine A, Martin L, Absy ML, Soubies F, Suguio K, Volkeimer-Ribeiro C. 1998. Amazon forest fires: a Lacustrine report of 7000 years. Ambio 27(2): 139-42.

Vandal GM, Fitzgerald WF, Boutron CF, Candelone JP. 1993. Variations of mercury deposition to Antarctica over the past 34,000 years. Nature 362:621-3. 